\title{
Tools to aid post-wildfire assessment and erosion-mitigation treatment decisions
}

\author{
Peter R. Robichaud ${ }^{\mathrm{A}, \mathrm{B}}$ and Louise E. Ashmun ${ }^{\mathrm{A}}$ \\ A US Department of Agriculture, Forest Service, Rocky Mountain Research Station, \\ 1221 South Main Street, Moscow, ID 83843, USA. \\ ${ }^{B}$ Corresponding author. Email: probichaud@fs.fed.us
}

\begin{abstract}
A considerable investment in post-fire research over the past decade has improved our understanding of wildfire effects on soil, hydrology, erosion and erosion-mitigation treatment effectiveness. Using this new knowledge, we have developed several tools to assist land managers with post-wildfire assessment and treatment decisions, such as prediction models, research syntheses, equipment and methods for field measurements, reference catalogues and databases of past-practice, and spreadsheets for calculating resource valuation and cost-benefit analysis. These tools provide relevant science to post-fire assessment teams and land managers in formats that often can be directly entered into assessment and treatment decision-making protocols. Providing public access to these tools through the internet not only has increased their dissemination, but also has allowed them to be updated and improved as new knowledge and technology become available. The use of these science-based tools has facilitated a broader application of current knowledge to post-fire management in the United States and in other fire-prone areas around the world.
\end{abstract}

Additional keywords: burn severity, erosion modeling, remote sensing, resource valuation.

Received 15 November 2011, accepted 2 May 2012, published online 2 August 2012

\section{Introduction}

Wildfires continue to be a major land-management concern throughout the world. The number and severity of wildfires has increased during the past several decades and the rise is likely to continue, especially in the western United States, Australia, and Mediterranean regions where drought and other effects of climate change are exacerbating wildfire conditions (Margaris et al. 1996; Flannigan et al. 2000; Williams et al. 2001; Westerling et al. 2006; Miller et al. 2009). At the same time, the number of people living in the wildland-urban interface continues to grow, putting human life and safety, infrastructure, homes, buildings, and natural areas that support livelihoods (grazing, timber, etc.) at risk from wildfire and secondary fire effects such as increased runoff, flooding, erosion, and debris flows (Moody and Martin 2009a). Mitigating these fire effects has resulted in increased use of post-fire treatments (Robichaud 2005; Robichaud et al. 2010).

For the past decade, our engineering research team (under Dr Robichaud) at the Rocky Mountain Research Station has focussed on understanding the effects of wildfire on hydrology and erosion, modelling and predicting those effects, and evaluating the capacity of post-fire treatments to reduce damage to values-at-risk (VAR) from increased flooding and erosion. Our research efforts, generally funded by US federal dollars, reflect the questions and needs of land managers working in public land agencies on post-fire stabilisation and rehabilitation. A general requirement for receiving public research funds is to identify and accommodate a valid public interest. In addition, government-funded research usually requires grantees to produce appropriate technology-transfer products and activities to facilitate moving new science findings into practice. The Joint Fire Science Program, a consistent and generous supporter of our research, has solicited and funded projects for the development and dissemination of tools that can directly impact the ability of land managers to put science into practice. Supporting these endeavours reflects the Joint Fire Science Program mission to 'focus on science delivery when research is completed...to ensure that managers are aware of, understand, and can use the information to make sound decisions and implement projects' (www.firescience.gov, verified 27 June 2012). Thus, it is not surprising that as scientists in a federal land-management agency whose research is supported in large part by competitive public funding, our research team has developed and disseminated many tools to improve the quality, timeliness, and effectiveness of post-fire assessment and erosion-mitigation treatment selection. This paper provides an overview of those tools, their use, and potential improvements that are under consideration.

The term 'tool' is applied broadly as any information, device, or method that puts research findings into a functional format for use by land managers in making decisions or implementing projects. Tools include predictive models, spreadsheets, maps, images, photo guides, field methods and equipment, decision trees, glossaries, databases and catalogues of past practice, and 
syntheses. Some tools require a user guide on how to interpret and apply the output to management tasks or significant training for users to become proficient. However, research can impact management practices more successfully when accurate, userfriendly tools are available - especially when tools target complex and time-consuming management tasks. For example, in 1995 a user interface was released for the Water Erosion Prediction Project (WEPP) soil-erosion model, a complex model adapted for agriculture, rangeland, and forest land (Flanagan and Livingston 1995). In the following 3 years, $\sim 200$ forest specialists were trained to use the WEPP model; yet only three or four of those trained specialists subsequently applied the model because of difficulties in assembling the input data, operating the interface, and interpreting the output (Elliot 2004). To facilitate a greater number of forest users to access the erosion- and sedimentation-prediction capabilities of the WEPP, a suite of simplified user interfaces was developed for a range of climatic and forest disturbances, including roads, fires, and timber harvest. These interfaces, accessed and run on the internet, limit needed user inputs to a few essential variables with other input variables automatically retrieved from internal databases. Outputs are generally designed to match the specific information and formats needed by forest managers for their work. The Forest Service WEPP (FSWEPP) internet interfaces were introduced in 2000, and within 1 year more than 600 users had used the WEPP model through the interfaces (Elliot 2004). Additional interfaces have been added to the FSWEPP suite and annual use has continued to expand with 29100 mean annual model runs since 2006.

The impetus for developing or modifying a tool for use in the post-fire environment often starts with the managers and specialists who work in the field. They may request assistance applying research findings in their work, such as when a postfire assessment team member asks for advice selecting and using an erosion-prediction model or discusses treatment options for a current post-fire situation. Such inquiries clarify management needs and may result in how-to manuals, field guides, etc. Other tools are developed as deliverables within funded research projects where technology transfer is required by the funding agency. Often these technology-transfer products are workshops and training activities designed to transfer new knowledge from researchers to the land-management community; however, new tools, such as online databases and user manuals, may also be developed. Research funding has supported projects for specific tool development; our research team has used such funding to develop new FSWEPP interfaces and syntheses of current knowledge. Many tools are at least partially developed before anyone asks for them because of a perceived potential for the tool. This rationale motivated our development of a protocol for using a mini-disk infiltrometer (MDI) to assess post-fire soil water repellency and the use of high-resolution remotely sensed imagery to map burn severity and monitor invasive weeds.

No matter what the impetus, tool development rarely follows a linear path from inception to completion. It generally includes creation (designing, writing, programming, etc.), validation, refinement, user training, field evaluations, and further cycles of refinement and testing as new information and user responses become available. Many of these steps or activities occur simultaneously, moving the entire process towards completion.
Occasionally, tool development will spur new research by exposing knowledge gaps and field contingencies that have not been adequately studied.

This discussion of tools designed to assist land managers with work in the post-wildfire environment is divided into two sections - post-fire assessment tools and post-fire treatment decision-making tools. As new knowledge and technologies become available, the function of existing tools may be improved by expanding the scope of applicability, simplifying the interface or output, improving accuracy, etc. Current efforts to improve these tools are also discussed.

\section{Post-fire assessment tools}

Post-fire impacts on the environment (also referred to as secondary fire effects) are incorporated into the concept of burn severity and are generally assessed and classified as low, moderate, or high burn severity (Jain et al. 2004; Lentile et al. 2006). In post-fire assessments, it has proven useful to divide burn severity into 'vegetation burn severity' and 'soil burn severity'. Vegetation burn severity classifies the effects of a fire on vegetative ecosystem properties and depends on the fire intensity (amount of energy or heat released per unit time or area during the consumption of organic matter, Keeley 2009) and the fireresistant properties of the ecosystem (Morgan et al. 2001; Lentile et al. 2006). In contrast, soil burn severity classifies the effects of fire on the ground surface and near-surface soil and is based on fire-induced changes in physical, chemical, and biological soil properties. Recently, there has been an intentional effort to use the term 'soil burn severity' to differentiate post-fire soil properties from fire effects on vegetation (such as tree mortality) or general fire effects on long-term ecosystem health (Parsons et al. 2010).

Fire-effects research continues to refine our understanding of the factors that impact post-fire watershed response to hydrological events. Some factors, such as rainfall characteristics, topography, soil type, and pre-fire land use, are inherent to the area and not directly tied to the fire. In particular, rainfall intensity has been positively associated with large post-fire runoff and erosion responses (Spigel and Robichaud 2007; Moody and Martin 2009a). The other characteristics that directly affect watershed response, such as remaining ground cover, soil erodibility, infiltration rate, and time since the fire, are attributed directly to the fire that occurred (DeBano et al. 1998, 2005; Neary et al. 2005a; Cerdà and Robichaud 2009; Moody and Martin 2009b). With the exception of time since fire, the firerelated factors are incorporated into the classification of soil burn severity, and as soil burn severity increases, the potential watershed response increases. However, the potential watershed response is moderated by the time since fire (recovery time) and tends to decrease as time since fire increases (Neary et al. 2005a).

A map of soil burn severity enables post-fire assessment teams to identify potential areas of concern and prioritise initial field reconnaissance (Parsons et al. 2010). In the past, these maps were drawn by hand from aerial and ground-based observations, but post-fire assessment teams found this increasingly challenging as fires became larger and burned areas more inaccessible. Currently, a combination of geospatial tools and 
field measurements are used to produce a map that depicts the general distribution of soil burn severity as accurately and quickly as possible (Clark and Bobbe 2006; Parsons et al. 2010). With a field-validated soil burn severity map, post-fire assessment teams can more readily evaluate potential wildfire effects including increased runoff, flooding, erosion and sedimentation, vulnerability to invasive weeds, and potential recovery time (Neary et al. 2005a; Calkin et al. 2007; Robichaud et al. 2008).

\section{Mapping burn severity \\ Remote sensing}

Post-fire soil burn severity mapping does not require the use of remote sensing or geographic information systems (GIS); however, both technologies are commonly used on large wildfires to improve the speed, precision, and accuracy of post-fire mapping efforts. Since 2002, the US Department of Agriculture, Forest Service, Remote Sensing Applications Center and the US Geological Survey, Center for Earth Resources Observation and Science have used pre- and post-fire Landsat (US remotesensing satellite program) satellite images of the burned area to derive a preliminary classification of landscape change. The differences between the pre- and post-fire image data form a continuous raster GIS layer that is classified into four burn severity classes - unburned, low, moderate, and high. This product is referred to as the Burned Area Reflectance Classification (BARC) map (Clark and Bobbe 2006) and is usually the starting point for the soil burn severity map on most fires (Orlemann et al. 2002).

The BARC is not considered a soil burn severity map until it has been field verified and, if necessary, adjusted to reflect the actual post-fire soil conditions (Parsons et al. 2010). In many cases, the BARC threshold values that divide the burn severity classes do not provide a satisfactory fit to the observed post-fire soil and ground conditions. Satellite sensors measure reflectance from the uppermost layer and, as a result, often reveal the vegetative (canopy) conditions more directly than soil or ground conditions. By making systematic adjustments to the break points between the severity classes, the BARC map may be brought into closer alignment with field observations (Parsons et al. 2010). Other situations may require adjustments in localised areas. Clouds, snow, smoke from surrounding fires, or large water bodies create inconsistencies in satellite imagery data. Land-use changes and management activities that occur between the pre- and post-fire satellite images can also create localised errors in the BARC soil burn severity classifications (Parsons et al. 2010). Whether systematic or localised, field observations of soil burn severity are integrated into the BARC map to generate a soil burn severity map of the fire.

At this time, new and archived Landsat imagery is readily available, but the federal funding for this program is not guaranteed making the future of the Landsat program somewhat uncertain. In addition, Landsat images have a 'moderate' ground resolution of $\sim 30 \mathrm{~m}$, which is coarser than the scale of postwildfire effects on soil and vegetation (Hudak et al. 2007), and because of a satellite-system malfunction, not all land areas are equally well imaged on each satellite pass, resulting in image data gaps. For these reasons, other remote sensing products are being evaluated for their application to assessing soil burn severity. Although higher-resolution imagery is available, images tend to be more expensive and difficult to obtain and processing times may be weeks or months (Robichaud et al. 2007a). For example, QuickBird (DigitalGlobe, Longmont, CO, USA) satellite images have $0.6-2.4 \mathrm{~m}$ pixel resolution, which is similar to the scale of variability found in post-fire soil characteristics of interest. Hyperspectral images, which have 1-5 m spatial resolution and high spectral resolution, can be obtained by flying a sensor-equipped aircraft over the site, and these images have been successfully correlated with soil burn severity (van Wagtendonk et al. 2004; Kokaly et al. 2007; Lewis et al. 2007; Robichaud et al. 2007a). When compared with BARC maps, the maps generated from these higher-resolution sensors are more precise and may better reflect the variability in postfire ground conditions, but the high cost, both in time and money, effectively precludes their immediate use in post-fire management (Kokaly et al. 2007; Robichaud et al. 2007a).

\section{Field guide for mapping post-fire soil burn severity}

A recently developed field guide provides a decision-making protocol to assist with soil burn severity mapping (Parsons et al. 2010). This field guide is designed for use by post-fire assessment teams to improve consistency of soil burn severity mapping by identifying key indicators of soil conditions that define the soil burn severity classes. Included in the field guide are guidelines for identifying soil burn severity classes, a photo series illustrating representative post-fire soil and ground conditions, and field data sheets to assist in data collection. Observations can be compared with those in the tables and photos to determine the soil burn severity classification at each field location. The Field guide for mapping post-fire soil burn severity can be used to field-validate the soil burn severity classes defined through remote sensing (for example, BARC) or as a reference for hand mapping when remotely sensed data are inadequate or not available. The guide also provides a description of mapping concepts and step-by-step instructions for mapping soil burn severity.

The field guide directs the user to make five observations (ground cover; ash colour and depth; soil structure; roots; and soil water repellency) at 10 data-collection locations for each field site (Fig. 1). Some observations require an approximate measurement (ground cover) while others require a comparison to unburned conditions (change in fine roots). Where possible, observations are categorised by selecting from a list the best descriptor that corresponds to soil burn severity classifications. For example, the three categories of ground cover observations are greater than $50 \%, 20-50 \%$, and less than $20 \%$, which correspond to low, moderate, or high soil burn severity (Fig. 1). The five observed factors do not have to reflect the same level of soil burn severity - 'the presence of two or more factors of high soil burn severity dominating an area may justify a classification of high soil burn severity for that polygon' (Parsons et al. 2010).

\section{Mini-disk infiltrometer (MDI)}

Soil water repellency is one of the five factors used to assess post-fire soil burn severity, and it is a required component of the 


\begin{tabular}{|c|c|c|c|c|c|c|c|c|c|c|}
\hline \multicolumn{3}{|c|}{$\begin{array}{l}\text { Soil Burn Severity Assessment } \\
\text { Field Data Form }\end{array}$} & \multicolumn{5}{|l|}{ Fire Name: } & \multicolumn{3}{|c|}{ Observers: } \\
\hline \multicolumn{2}{|l|}{ Date: } & Site ID: & \multicolumn{5}{|c|}{ GPS Coordinates: } & \multicolumn{3}{|c|}{ BARC Classification: } \\
\hline $\begin{array}{l}\text { Observation } \\
\text { Point }\end{array}$ & $\begin{array}{l}\text { Ground } \\
\text { cover (1) }\end{array}$ & \multirow{2}{*}{$\begin{array}{c}\begin{array}{c}\text { Surface Color and } \\
\text { Ash Depth (2) }\end{array} \\
\text { white, } 1 \mathrm{~mm}\end{array}$} & \multirow{2}{*}{\begin{tabular}{|c|}
$\begin{array}{c}\text { Soil } \\
\text { Structure } \\
(3)\end{array}$ \\
no change \\
\end{tabular}} & \multirow{2}{*}{$\begin{array}{l}\text { Roots } \\
\text { (4) } \\
\text { intact }\end{array}$} & \multicolumn{3}{|c|}{$\begin{array}{c}\text { Soil Water } \\
\text { Repellency (5) }\end{array}$} & \multirow{2}{*}{$\begin{array}{c}\text { Observed } \\
\text { Soil Burn } \\
\text { Severity } \\
\text { Class (6) } \\
\text { Mod } \\
\end{array}$} & \multirow{2}{*}{\begin{tabular}{c|} 
Photo \# \\
23
\end{tabular}} & \multirow{2}{*}{$\begin{array}{c}\begin{array}{c}\text { Other } \\
\text { Comments }\end{array} \\
\text { homogenous }\end{array}$} \\
\hline EXAMPLE & 20 to $50 \%$ & & & & $I$ & $3 \mathrm{~mL}$ & surf & & & \\
\hline \multicolumn{11}{|l|}{1} \\
\hline \multicolumn{11}{|l|}{2} \\
\hline \multirow{2}{*}{\multicolumn{11}{|c|}{$\begin{array}{l}3 \\
4\end{array}$}} \\
\hline & & & & & & & & & & \\
\hline \multicolumn{11}{|l|}{5} \\
\hline \multirow{2}{*}{\multicolumn{11}{|c|}{$\frac{6}{7}$}} \\
\hline \multirow{2}{*}{\multicolumn{11}{|c|}{$\frac{7}{8}$}} \\
\hline & & & & & & & & & & \\
\hline \multicolumn{11}{|l|}{9} \\
\hline \multicolumn{11}{|l|}{10} \\
\hline \multicolumn{11}{|l|}{$\begin{array}{l}\text { Average/Majority } \\
\quad \text { for Site (7) }\end{array}$} \\
\hline \multicolumn{2}{|c|}{ Site Characteristics: } & \multicolumn{2}{|l|}{$\begin{array}{l}\text { Aspect (deg): } \\
\text { Slope Position: }\end{array}$} & \multicolumn{4}{|c|}{ Slope \%: } & & & \\
\hline \multicolumn{2}{|c|}{ Slope Length (ft or $\mathrm{m}$ ): } & Slope Position: & Lower & Midd & & & per & Ridge & Other & \\
\hline \multicolumn{2}{|c|}{$\begin{array}{l}\text { Soil Texture Class: } \\
\text { clay loam, silt loam, loam }\end{array}$} & $\begin{array}{l}\text { Dominant Pre-Fire } \\
\text { Vegetation Type }\end{array}$ & \multirow{3}{*}{\multicolumn{2}{|c|}{$\begin{array}{l}\text { Pre-Fire Vegetation } \\
\text { Density } \\
\text { Low } \\
\text { High } \\
\text { Other }\end{array}$}} & \multirow{3}{*}{\multicolumn{3}{|c|}{$\begin{array}{l}\text { Vegetation } \\
\text { Comments: }\end{array}$}} & \multirow{3}{*}{\multicolumn{3}{|c|}{$\begin{array}{l}\text { Other } \\
\text { Notes: }\end{array}$}} \\
\hline \multirow{2}{*}{\multicolumn{2}{|c|}{$\begin{array}{l}\text { Surface Rock \%: } \\
\text { Soil Comments: }\end{array}$}} & Chaparral & & & & & & & & \\
\hline & & $\begin{array}{c}\text { Forest } \\
\text { Sagebrush/grassland } \\
\text { Other }\end{array}$ & & & & & & & & \\
\hline
\end{tabular}

Fig. 1. Post-fire assessment field data sheet from the Field guide for mapping post-fire soil burn severity (Parson et al. 2010, appendix B).

current Burned Area Emergency Response (BAER) assessment report (USDA Forest Service 2004). The Water Drop Penetration Time test has been the common field test for soil water repellency (DeBano 1981). Because soil water repellency has a large impact on soil infiltration characteristics, the degree and extent of post-fire soil water repellency is often used to estimate the reduced infiltration rate used for modelling post-fire hydrological processes (Pierson et al. 2001; Robichaud 2000). Recently, a MDI has been adapted for use as a field test of post-fire soil water repellency and infiltration (Robichaud et al. 2008) (Fig. 2). The MDI field test provides a relative infiltration rate that not only reflects existing soil water repellency, but also reflects soil sealing and other factors that may impact post-fire infiltration rates. The Field guide for mapping post-fire soil burn severity is designed to accommodate either the Water Drop Penetration Time or the MDI field tests for soil water repellency assessment (Parsons et al. 2010). The MDI test protocol and sampling method described in New Procedure for Sampling Infiltration to Assess Post-fire Soil Water Repellency (Robichaud et al. 2008) was specifically developed to provide a rapid, practical evaluation of burned soil infiltration characteristics for post-fire assessment. It includes instructions for using a MDI, field data sheets, detailed sampling scheme with pre-determined sample size and confidence levels, and a formatted data analysis spreadsheet tool for use in post-fire assessment.

The ease of using the MDI in the field has prompted ongoing efforts to correlate post-fire infiltration rates, as measured by rainfall simulation, to MDI measurements. Efforts to determine these correlations have been hindered by the large temporal and spatial variability of soil water repellency and post-fire infiltration rates as well as the relatively small number of post-fire

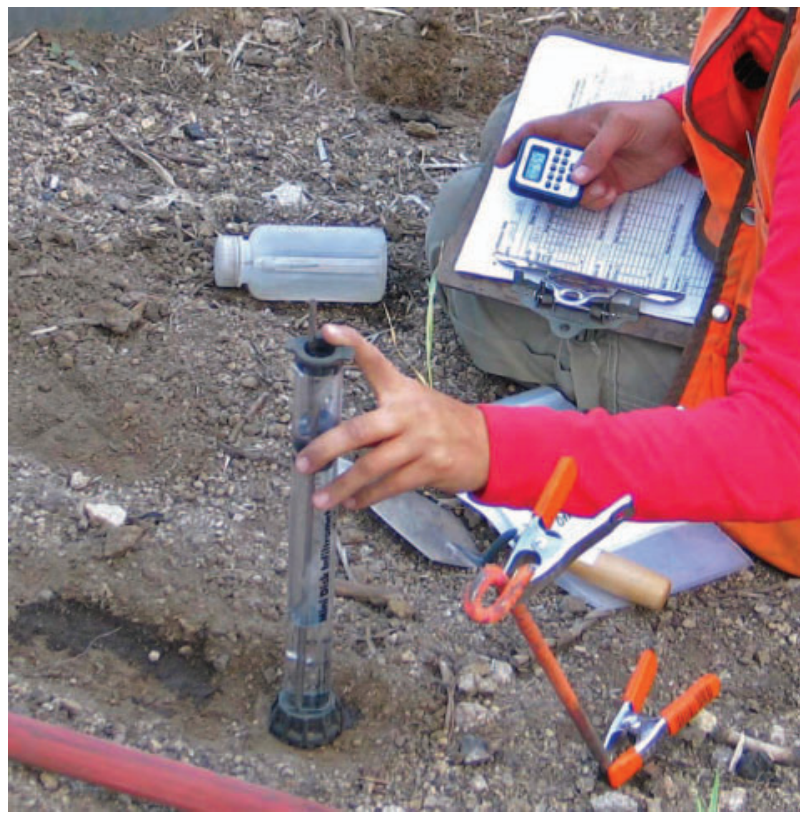

Fig. 2. Using the mini-disk infiltrometer in the field (from Robichaud et al. 2008).

rainfall simulation studies that include MDI tests for soil water repellency. Since infiltration is an important input for predictive hydrological and erosion models, it would be useful to derive an estimate of the infiltration rate from a field-measurement protocol such as the MDI. 


\section{Post-fire treatment decision tools}

Soil burn severity is combined with climate (particularly rainfall regimes), topography, soil type, and pre-fire vegetation to predict the potential hydrological and erosion response of burned watersheds. These predictions, in combination with identified VAR, are evaluated to determine if and where post-fire treatments are justified (Robichaud 2005; Foltz et al. 2009; Robichaud et al. 2010). Several tools have been developed for these tasks. Hydrological and erosion models have been adapted for burned landscapes, and an economic valuation tool has been developed to calculate the economic justification for using postfire treatments to reduce potential damage and loss to VAR.

\section{Hydrological and erosion modelling}

Hydrological and erosion response predictions are generally made using a combination of models and techniques. Post-fire treatment decisions, particularly decisions concerning road and channel treatments, rely on viable estimates of potential postfire runoff and peak flows and to a lesser degree on erosion estimates, while hillslope treatment decisions are mostly based on potential erosion estimates. Estimates of rainfall and runoff are needed to predict erosion and are part of most erosion prediction models, yet they are not always included in the output. Consequently, post-fire assessment teams frequently use two or more models to obtain the estimates they need.

\section{Estimating peak flows}

In the US, post-fire assessment teams select from a variety of available models to estimate pre- and post-fire peak flows based on design storms. Ideally, the user would select the most effective and accurate model for the available information and site conditions. However, in practice the selected models and methods are often the ones most familiar to the user (Foltz et al. 2009). An estimation of peak flows and runoff are most often accomplished using a model based on either the US Geological Survey Regression Equations (Thomas et al. 1997) or one of several models that incorporate Curve Number $(\mathrm{CN})$ methods (Ponce and Hawkins 1996). In StreamStat (http://water.usgs. gov/osw/streamstats, verified 27 June 2012), the US Geological Survey regression method is adapted to a burned area by including the fraction of the area burned at high and moderate severity as an input and as a part of the 'modifier' calculation for estimating post-fire runoff. CN models used for post-fire assessment include WILDCAT4 (Hawkins and Greenberg 1990), HYDRO (Cerrelli 2005), and WinTR-55 (Natural Resources Conservation Service 2005). These models require a userselected $\mathrm{CN}$ based on cover type, treatment (the model includes a soil burn severity option), hydrological conditions, and hydrological soil group. Although the $\mathrm{CN}$ is the single most-important parameter in this method, its selection for post-fire conditions is not straightforward or consistent (Foltz et al. 2009). We have developed a new web-based peak flow calculation model based on $\mathrm{CN}$ methods that allows the user to directly input a $\mathrm{CN}$ value or accept an estimated $\mathrm{CN}$ value based on the output from the Erosion Risk Management Tool (ERMiT), an erosion prediction model (Elliot et al. 2010) described below. The peak flow calculator is currently available at: http://forest.moscowfsl. wsu.edu/fswepp/ermit/peakflow (verified 27 June 2012).
Several of the peak flow models discussed above are also available within our website at: http://forest.moscowfsl.wsu. edu/BAERTOOLS/ROADTRT/Peakflow/ (verified 27 June 2012).

\section{Estimating erosion}

Estimation of potential post-fire erosion is often accomplished using the FSWEPP interfaces (Elliot 2004; Robichaud et al. 2007b) - adaptations of WEPP (Flanagan and Livingston 1995) for forest and rangeland environments. The climate file that drives WEPP is stochastically generated from historical weather station data and modified by the Rock Clime interface for mountainous regions (Elliot 2004). WEPP and the full suite of FSWEPP interfaces can be accessed online at: http://forest. moscowfsl.wsu.edu/fswepp (verified 27 June 2012).

There are several FSWEPP interfaces that calculate potential post-fire erosion rates, such as Disturbed WEPP (Elliot 2004), ERMiT (Robichaud et al. 2006, 2007b), and GeoWEPP (Renschler 2008) (Fig. 3). Disturbed WEPP allow users to describe numerous disturbed forest and rangeland erosion conditions including low and high soil burn severity conditions. The interface output provides mean annual runoff depth, erosion rates, sediment yields, and the probability of a given amount of erosion occurring the year following a disturbance. ERMiT was developed specifically for post-fire assessments. Using a simplified interface for inputs (Fig. 4), ERMiT predicts the probability associated with a given hillslope sediment yield (untreated, Fig. 5, and treated with seeding, dry agricultural straw mulching, or erosion barriers) from a single storm in each of 5 years following wildfire (Robichaud et al. 2006, 2007b). In addition, ERMiT Batch is available as a downloadable spreadsheet that is designed to make running multiple ERMiT scenarios much more efficient; input data can be entered manually or imported via a GIS toolbox (http://forest.moscowfsl.wsu.edu/ fswepp/batch/bERMiT.html, verified 12 July 2012). GeoWEPP develops a drainage network for the region selected, and then defines the channel network and hillslope polygons for a watershed that is selected by defining the watershed outlet for pre- and post-fire conditions (Renschler 2008). GeoWEPP utilises two modes - flowpath and watershed. Flowpath mode predicts runoff and erosion for every pixel within the selected watershed. Watershed mode predicts runoff and peak flow values as well as sediment delivery from each hillslope polygon and stream channel segment identified.

Future refinement of the FSWEPP interfaces will enable the model to accept inputs from GIS sources and produce reliable estimates of post-fire runoff, peak flow, and erosion with userfriendly output formats that are integrated with GIS and other post-fire assessment tools. In addition, post-fire models for wind erosion and dry ravel (gravity-driven) erosion are currently being developed.

\section{Syntheses of post-fire erosion research}

Prediction models are very useful in post-fire decision making; however, models generally provide an annual average or, more recently, a range of expected outcomes that may require professional judgment to apply to the specific conditions of an 

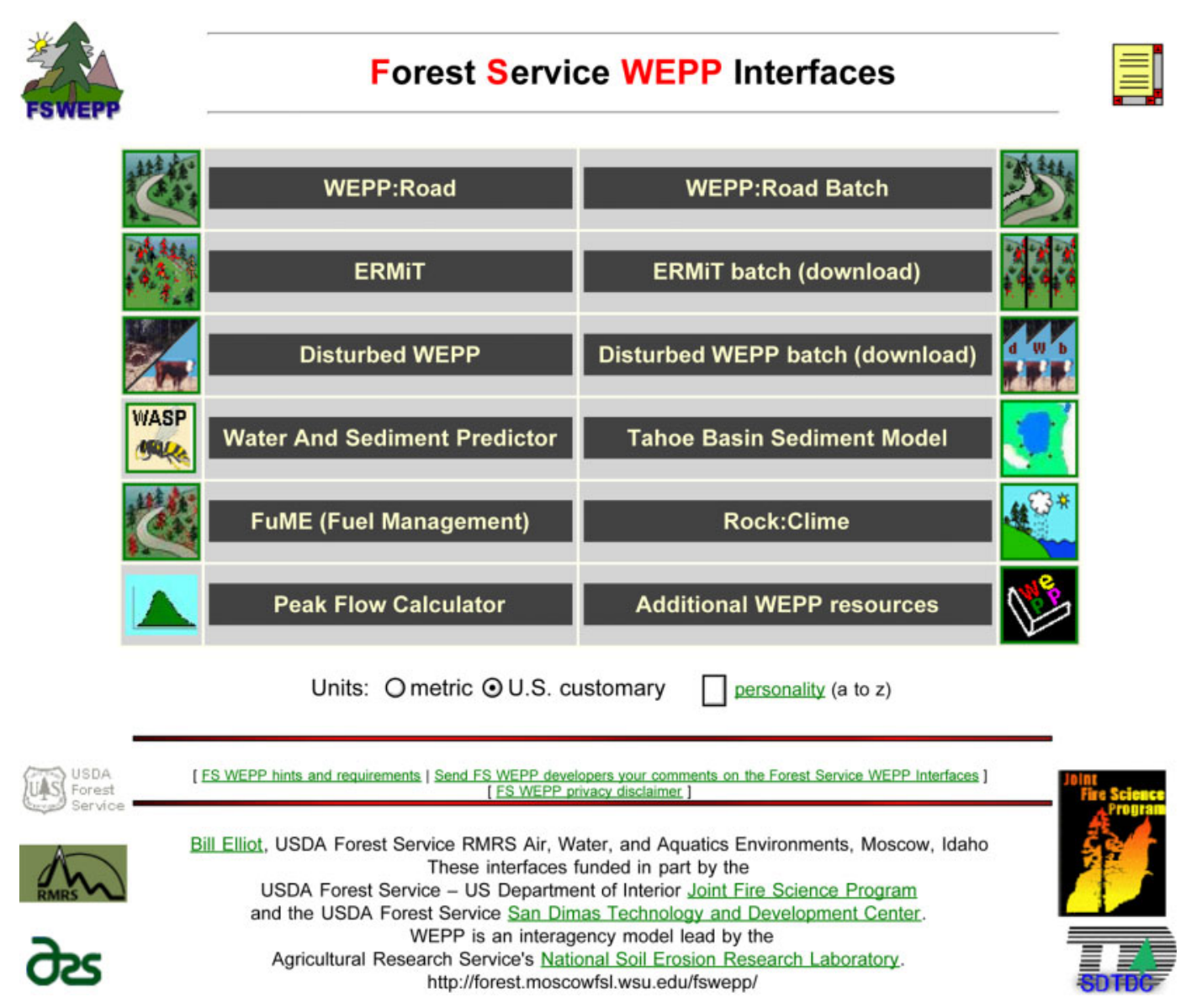

Fig. 3. The opening web page for user selection of available Forest Service Water Erosion Prediction Project interfaces [screen capture] (http://forest.moscowfsl.wsu.edu/fswepp/, verified 27 June 2012).

individual fire. By comparing model predictions to reported erosion rates, post-fire assessment teams can validate model predictions. Recent research syntheses that include measured post-fire erosion rates include 'Synthesis of sediment yields after wildland fire in different rainfall regimes in the western United States' (Moody and Martin 2009a), Fire effects on soils and restoration strategies (Cerdà and Robichaud 2009), and Wildland fire in ecosystems: effects of fire on soil and water (Neary et al. 2005b). Syntheses may also provide insight as to the storm intensities and sediment yields that have had damaging consequences in the past.

\section{Post-fire treatment decisions}

Using the post-fire soil burn severity map and predictive models to determine the likelihood of damaging floods and erosion occurring, post-fire assessment teams can then recommend land treatments, road improvements, channel treatments, and warning systems that will mitigate these and other threats. In the US, post-fire assessment teams that request funding for treatments must show that the threats of increased runoff, erosion, flooding, sedimentation, or vulnerability to invasive weeds will likely cause loss or damage to life, property, and/or resources. With the important exception of public safety, they must also show that the cost of recommended treatments is justified based on the value of the threatened resource, the probability that the treatment will be successful, and the cost of the treatment itself.

\section{Assessing post-fire VAR with a new calculation tool}

Recently, a spreadsheet calculation tool (Calkin et al. 2007) was developed to aid in assessing post-fire VAR in connection with treatment decisions. Cost-benefit analysis is fairly straightforward when the cost of repair or replacement of the VAR can be determined; however, it becomes much more complicated for non-market VAR (such as sensitive wildlife species, undeveloped recreation, cultural artefacts). The time and economic expertise needed for valuation of non-market resources are rarely, if ever, available to post-fire assessment teams. In this valuation tool, a non-market VAR is assessed in terms of its implied minimum value (IMV $=$ treatment cost/ change in likelihood of loss or damage due to treatment). Once the IMV is determined, the assessment team and the funding agency must determine if the IMV justifies the use of public funds to mitigate potential damage or loss of that resource (Calkin et al. 2007) (Fig. 6).

Post-fire treatment calculations for both market and nonmarket VAR require an estimate of the probability of damage or loss occurring and the probability of treatment success as inputs (Fig. 6). Although we know that some treatments are more 

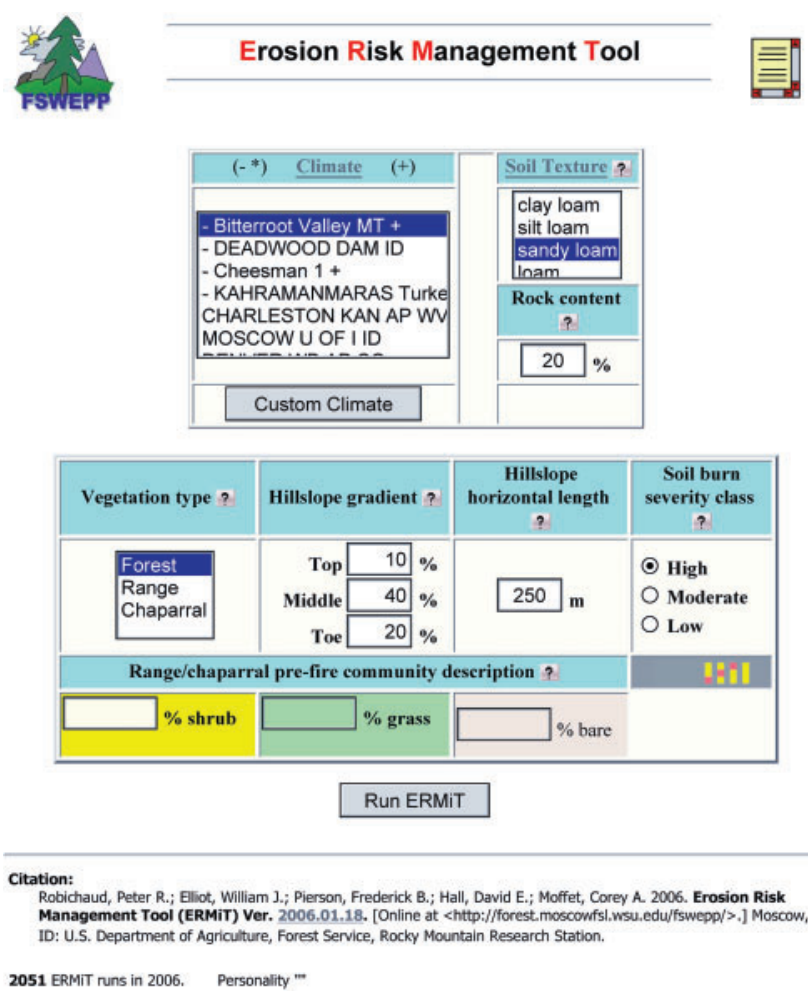

Fig. 4. The Erosion Risk Management Tool input screen with sample user selections shown [screen capture]

effective than others (Table 1), the process for estimating the probability of treatment success (in other words, the reduction in risk due to treatment) is not an exact science. The tabular output from ERMiT can be used to estimate the probability of hillslope treatment success for seeding, erosion barriers, and dry agricultural straw mulch (Calkin et al. 2007), but it currently is limited to those treatments. The likelihood of treatment success is generally a professional judgment based on past experience, treatment effectiveness research, and treatment catalogues (see Napper 2006). The valuation process developed by Calkin et al. (2007) is supported by the spreadsheet-based 'VAR Calculation Tool' that can be downloaded from our website (http://forest. moscowfsl.wsu.edu/BAERTOOLS, verified 27 June 2012) (Fig. 6).

\section{Post-fire treatment information}

Once it is decided that treatments are needed, choosing the best treatments for a particular site requires access to treatment effectiveness and performance information. Realistic assessments of post-fire treatment effectiveness are essential if postfire assessment teams are to choose treatments that balance protection of public safety and VAR with justifiable, costeffective expenditures of public funds. Managers also need to know how and why treatments work so they can determine the best treatment(s) for a specific location and decide how to adapt treatments to improve their effectiveness. For example, the formulation and application rate of mulches can be modified to enhance performance characteristics such as longevity, adherence to soil, and interlocking of mulch strands. The

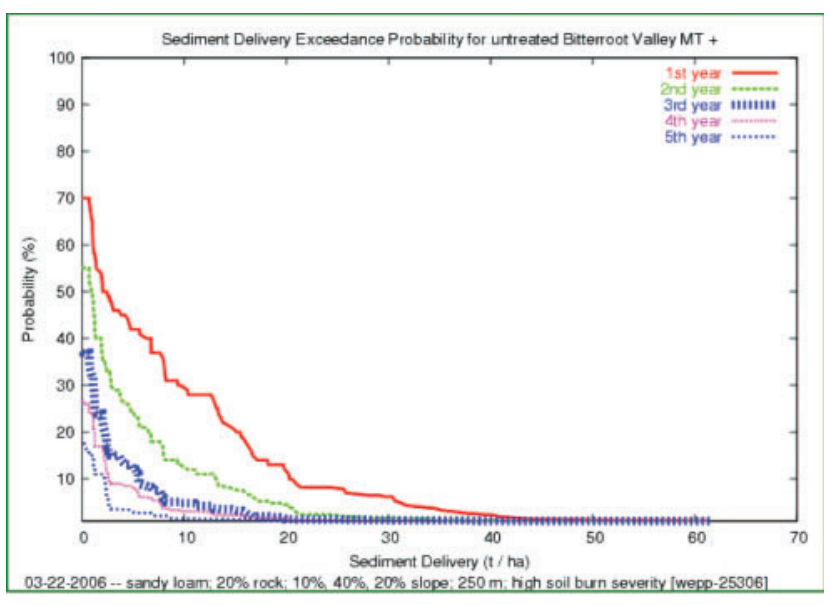

Fig. 5. An Erosion Risk Management Tool output graph showing exceedance probability versus event sediment delivery for 5 years after the fire from a modelled, untreated hillslope [screen capture].

importance of such characteristics is dependent on specific site characteristics such as steepness, exposure to high winds, and general rate of vegetative recovery.

Post-fire treatment syntheses and treatment catalogues provide current information on various treatments in formats that are easily used by post-fire assessment teams. Recently published treatment syntheses include the Burned area emergency response treatments catalog (Napper 2006), A synthesis of postfire road treatments for BAER teams (Foltz et al. 2009), Post-fire treatment effectiveness for hillslope stabilization (Robichaud et al. 2010), which are available at the BAERTOOLS website (http://forest.moscowfsl.wsu.edu/ BAERTOOLS, verified 27 June 2012), and Post-wildfire seeding in forests of the western United States: An evidence-based review (Peppin et al. 2010).

Research on post-fire treatments continues to evolve. Not only are new treatment materials and methods being developed and refined, but treatment research is expanding to include longterm effects of treatments on soil and post-fire recovery, wind erosion mitigation, and headwater channel treatments.

\section{International issues}

The post-wildfire management issues that drive much of our work are not unique to the United States. The post-fire assessment tools developed for the US have been used by managers and researchers in many countries, including Argentina, Australia, Canada, Greece, Italy, Israel, Lebanon, Mexico, Portugal, Spain, and Turkey. Research publications on fire effects, post-fire modelling, and treatment effectiveness have an international readership. However in some countries, the process has gone beyond the sharing of information; concerted efforts have been made to evaluate and adapt portions of the US post-fire assessment and treatment recommendation protocol for use within their land management agencies.

After a devastating bushfire in 2009, Australia requested US assistance with the post-fire assessment and treatment decisions and three US BAER 12-member teams were deployed in response. These BAER teams worked closely with their Australian counterparts over a 2-month period. Subsequently, the State 


\begin{tabular}{|c|c|c|c|}
\hline Fire Name & Santiago Fire & \multirow{3}{*}{\multicolumn{2}{|c|}{ Live Oak Canyon }} \\
\hline Location & Orange County, CA & & \\
\hline \multicolumn{2}{|c|}{$\begin{array}{l}\text { Date } 11 / 18 / 2007 \\
\text { EACH MAP ZONE REPRESENTS A SYSTEM OF LINKED TREATMENTS AND ASSOCIATED VALUES AT RISK }\end{array}$} & & \\
\hline \multicolumn{4}{|c|}{ EACH MAP ZONE REPRESENTS A SYSTEM OF LINKED TREATMENTS AND ASSOCIATED VALUES AT RISK } \\
\hline Map link\# & Life and Safety & \multicolumn{2}{|l|}{ Description } \\
\hline & Debris Flow and flood threat & \multirow{2}{*}{\multicolumn{2}{|c|}{$\begin{array}{l}\text { Throughout canyon floor adjacent to streams } \\
\text { SHOULD NOT BE RELEVANT AND SHOULD STRICTLY BE AN ACCOUNTING EXERCISE }\end{array}$}} \\
\hline \multirow{2}{*}{\multicolumn{2}{|c|}{ PLEASE NOTE: IF PUBLIC SAFETY IS A FACTOR, B/C RATIO SHOULD NOT BE RELEVANT AND SHOULD STRICTLY BE AN ACCOUNTING EXERCISE }} & & \\
\hline & & \multicolumn{2}{|l|}{ Description } \\
\hline Map link\# & Non-Market: Cultural Values & \multirow{2}{*}{\multicolumn{2}{|c|}{ 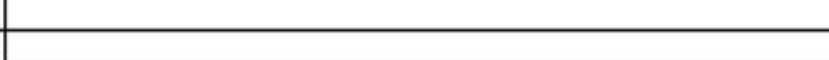 }} \\
\hline \multirow{2}{*}{ Map link\# } & & & \\
\hline & Non-Market: Ecological & \multicolumn{2}{|l|}{ Description } \\
\hline & & & \\
\hline & & & \\
\hline \multirow[t]{4}{*}{ Map link \# } & Market Values: Direct & Description & Total \\
\hline & 4 Structures & Assumed to be residential & $2,321,092$ \\
\hline & 1 water tank & estimated - no data available & 100,000 \\
\hline & & & $\$$ \\
\hline \multirow[t]{4}{*}{ Map link \# } & Market Values: Loss-of-Use & Description & \\
\hline & & & $\$$ \\
\hline & & & $\$$ \\
\hline & & & \\
\hline \multicolumn{3}{|c|}{ Probability of experiencing the loss with no treatment (enter as decimal) } & 0.500 \\
\hline \multirow{2}{*}{\multicolumn{3}{|c|}{ Source of loss probability with no treatment: }} & \\
\hline & & & $2,421,092$ \\
\hline \multicolumn{4}{|c|}{ TREATMENT DESCRIPTION } \\
\hline \multirow[t]{4}{*}{ Map link\# } & Proposed treatment & & Total \\
\hline & \multicolumn{2}{|c|}{$\begin{array}{l}\text { Proposed treatment } \\
\text { Hydromulching upper watershed - } 41 \text { acres }\end{array}$} & 143,680 \\
\hline & & $\$$ \\
\hline & & & $\$$ \\
\hline \multicolumn{3}{|c|}{ Probability of experiencing loss if treatment occurs (enter as decimal) } & 0.375 \\
\hline \multirow{2}{*}{\multicolumn{3}{|c|}{$\begin{array}{lr}\text { Source of loss probability with treatment: } & \text { Select Source... } \\
& \text { Total Treatment Cost }\end{array}$}} & \\
\hline & & & 143,680 \\
\hline \multicolumn{4}{|c|}{ VAR CALCULATION RESULTS } \\
\hline \multirow{3}{*}{\multicolumn{3}{|c|}{$\begin{array}{r}\text { REDUCTION IN PROBABILITY OF LOSS } \\
\text { EXPECTED BENEFIT OF TREATMENT } \\
\text { Expected Benefit/Cost ratio of treatment for market resources only (economically justified if }>1.0 \text { ) }\end{array}$}} & 0.125 \\
\hline & & & 302,637 \\
\hline & & & 2.1 \\
\hline & IMPLIED MINIMUM V & F PROTECTING NON-MARKET RESOURCE VALUES & JUSTIFIED \\
\hline
\end{tabular}

\section{Non-Market Values Literature $\quad$ View Literature}

Fig. 6. A worksheet (Map Zone D) from the values-at-risk calculation tool sample for the 2007 Santiago Fire [screen capture] (http:// forest.moscowfsl.wsu.edu/BAERTOOLS/VAR/, verified 27 June 2012).

of Victoria (Department of Sustainability and Environment) established Bushfire Rapid Risk Assessment Teams (Bushfire RRAT) that would use methods, tools, and rehabilitation techniques that had been learned by their work with the US BAER teams (Department of Sustainability, Victoria 2009). The Bushfire RRAT perform a rapid risk assessment and produce a written report of post-fire conditions and recommend riskmitigation strategies within 7 days. In addition, they assist fire and land managers transition from suppression to recovery. However, unlike the short-term US BAER response, the
Bushfire RRAT's report is designed to contribute to the development of longer-term rehabilitation and recovery plans.

In Greece, the Reforestation and Mountainous Hydrology Division of the Greek Forest Service developed guidelines for post-fire conservation practices (Myronidis and Arabatzis 2009). The guidelines focussed on post-fire stabilisation measures that would decrease the post-fire erosion potential, maintain the soil on the hillslopes, and trap the sediments in smaller tributary channels to avoid delivery downstream. US BAER technical advisors were requested to assist Greek land managers 
Table 1. Summary table of post-fire hillslope treatment effectiveness and performance characteristics

Overall effectiveness ratings for post-fire hillslope stabilisation treatment effectiveness for three rainfall regimes (high intensity, low intensity, and high total amount). Treatment effectiveness codes: $1=$ more effective; $2=$ somewhat effective; $3=$ not effective. Treatments rated as more likely (more) or less likely (less) to exhibit performance characteristics that impact treatment effectiveness, post-fire recovery, or the environment. Other phrases are used to describe the performance characteristics of treatments that are dependent on circumstances or are not effectively rated as more or less likely (from Robichaud et al. 2010, appendix A)

\begin{tabular}{|c|c|c|c|c|c|c|c|}
\hline & & Straw mulches & Wood mulches & Hydro-mulches & $\begin{array}{l}\text { Soil binders } \\
\text { (polyacrylamide) }\end{array}$ & $\begin{array}{l}\text { Contour-felled } \\
\text { logs (log erosion } \\
\text { barriers) }\end{array}$ & $\begin{array}{l}\text { Straw } \\
\text { wattles }\end{array}$ \\
\hline \multirow{2}{*}{$\begin{array}{l}\text { Overall effective- } \\
\text { ness (rating: } 1,2 \text {, } \\
\text { or } 3 \text { ) }\end{array}$} & Low-intensity rainfall & 1 & 1 & 1 & 2 & 1 & 1 \\
\hline & $\begin{array}{l}\text { High rainfall amount } \\
(>50 \mathrm{~mm} \text { in } 6 \mathrm{~h})\end{array}$ & 1 & 1 & 2 & 3 & 2 & 2 \\
\hline \multirow{7}{*}{$\begin{array}{l}\text { Performance } \\
\text { characteristics } \\
\text { that affect } \\
\text { effectiveness }\end{array}$} & Resistant to wind displacement & Less $^{\mathrm{A}}$ & More $^{\mathrm{A}}$ & More & More & More & More \\
\hline & $\begin{array}{l}\text { Remains functional for more } \\
\text { than } 1 \text { year }\end{array}$ & More & More & Less & Less & More & More \\
\hline & Provides ground cover & More & More & More & Less & Less & Less \\
\hline & Increases infiltration & More & More & Not known & $\begin{array}{r}\text { Depends on } \\
\text { conditions }\end{array}$ & Less & Less \\
\hline & $\begin{array}{l}\text { Increases soil moisture } \\
\text { retention }\end{array}$ & More & More & More & Less & Less & Less \\
\hline & Traps sediment & More & More & Less & Less & More & More \\
\hline & $\begin{array}{l}\text { Slows development of } \\
\text { concentrated flow }\end{array}$ & More & More & More & More & Less & Less \\
\hline \multirow{3}{*}{$\begin{array}{l}\text { Other } \\
\text { considerations }\end{array}$} & Contains noxious weed seeds & Possible & Less & Less & Less & Less & Possible \\
\hline & Delays revegetation & $\begin{array}{l}\text { Depends on } \\
\text { mulch } \\
\text { thickness }\end{array}$ & $\begin{array}{l}\text { Depends on } \\
\text { mulch } \\
\text { thickness }\end{array}$ & Less & Less & Less & Less \\
\hline & Harmful to the environment & Less & Less & $\begin{array}{l}\text { Depends on } \\
\text { components }\end{array}$ & $\begin{array}{l}\text { Depends on } \\
\text { type and } \\
\text { concentration }\end{array}$ & Less & Less \\
\hline
\end{tabular}

${ }^{\mathrm{A}}$ In wind tunnel tests, agricultural straw resisted movement in wind speeds of 15 miles h$^{-1}\left(6.5 \mathrm{~m} \mathrm{~s}^{-1}\right)$, and wood straw resisted movement in wind speeds of $40 \mathrm{miles} \mathrm{h}^{-1}\left(18 \mathrm{~m} \mathrm{~s}^{-1}\right)($ Copeland et al. 2009).

after the wildfires in 2009 , this technical assistant visit resulted in improvements to their assessment process, which is modelled on the US BAER program.

The British Columbia, Canada, Southern Interior Forest Region used components of the US BAER program to develop a systematic approach for post-wildfire risk assessment of severe surface erosion, landslide, gully processes, and flood events (Jordan et al. 2006). During the program development, numerous interactions occurred among the lead author and several Canadian specialists, including on-site visits. These interactions led to a joint US-Canadian research project evaluating the effectiveness of wood shreds, generated from burnt trees, and used as a mulch to reduce erosion on burned hillslopes (P. R. Robichaud, P. Jordan, S. A. Lewis, L. E. Ashmun, S. A. Covert, R. E. Brown, unpubl. data).

\section{Conclusion}

The tools that have been developed for post-fire assessment and erosion-mitigation treatment decisions have been the focus of much of our research team's work in the past decade. Increased knowledge of post-fire effects and improvements in the processes and tools available for post-fire assessment has allowed for more targeted and cost effective management. Efforts to make post-fire assessment tools and information accessible via the internet have allowed for quick access from remote locations. In addition, websites can be quickly updated - an advantage over published materials - and linked to relevant models, databases, etc. Consequently, the post-fire management tools developed in the United States, particularly those tools that are web-based and publicly accessible, are being used by land managers in fire-prone areas around the world.

\section{Acknowledgements}

We are grateful for over a decade of generous support from the Joint Fire Science Program, a cooperative effort of the US Department of Agriculture, Forest Service and Department of Interior. This research was also supported by the USDA Forest Service, Rocky Mountain Research Station and several National Forests where our studies have been done. Our research is integrated and dependent on all of the work done by the engineering research groups at the Moscow, Idaho Laboratory; thus we want to thank Drs William Elliot and Randy Foltz along with their research teams for the open collaboration that has resulted in so many useful tools. We also thank all the past and present BAERBONES RESEARCH associates whose hard work and enthusiasm for the often tedious and difficult tasks make this research not only possible but enjoyable. We thank three anonymous reviewers, the guest 
editor, and the journal editor who provided comments and suggestions that improved this manuscript.

\section{References}

Calkin DE, Hyde KD, Robichaud PR, Jones JG, Ashmun LE, Loeffler D (2007) Assessing post-fire values-at-risk with a new calculation tool. US Department of Agriculture, Forest Service, Rocky Mountain Research Station, General Technical Report RMRS-GTR-205. (Fort Collins, CO) Available at http://forest.moscowfsl.wsu.edu/BAERTOOLS/VAR/ [Verified 14 April 2012]

Cerdà A, Robichaud PR (2009) Fire effects on soil infiltration. In 'Fire effects on soils and restoration strategies'. (Eds A Cerdà, PR Robichaud) pp. 81-103. (Science Publishers: Enfield, NH)

Cerrelli GA (2005) FIRE HYDRO, a simplified method for predicting peak discharges to assist in the design of flood protection measures for western wildfires. In 'Proceedings of the 2005 Watershed Management Conference - Managing Watersheds for Human and Natural Impacts: Engineering, Ecological, and Economic Challenges', July 2005, Williamsburg, VA. (Ed. GE Moglen) pp. 935-941. (American Society of Civil Engineers: Alexandria, VA)

Clark JT, Bobbe T (2006) Using remote sensing to map and monitor fire damage in forest ecosystems. In 'Understanding forest disturbance and spatial patterns: remote sensing and GIS approaches'. (Eds MA Wulder, SE Franklin) pp. 113-128. (Taylor \& Francis: London)

Copeland NS, Sharratt BS, Wu JQ, Foltz RB, Dooley JH (2009) A woodstrand material for wind erosion control: effects on total sediment loss, $\mathrm{PM}_{10}$ vertical flux, and $\mathrm{PM}_{10}$ loss. Journal of Environmental Quality 38, 139-148. doi:10.2134/JEQ2008.0115

DeBano LF (1981) Water repellent soils: a state of the art. US Department of Agriculture, Forest Service, Pacific Southwest Forest and Range Experiment Station, General Technical Report PSW-46. (Berkeley, CA)

DeBano LF, Neary DG, Ffolliott PF (1998) 'Fire's effects on ecosystems.' (Wiley: New York)

DeBano LF, Neary DG, Ffolliott PF (2005) Soil physical properties. In 'Wildland fire in ecosystems: effects of fire on soil and water'. (Eds DG Neary, KC Ryan, LF DeBano) US Department of Agriculture, Forest Service, Rocky Mountain Research Station, General Technical Report RMRS-GTR-42-vol. 4, pp. 29-51. (Ogden, UT)

Department of Sustainability, Victoria (2009) Bushfire rapid risk assessment teams (RRAT). Available at http://www.dse.vic.gov.au/fire-and-otheremergencies/bushfire-recovery/bushfire-rapid-risk-assessment-teamsbushfire-rrats [Verified 11 April 2012]

Elliot WJ (2004) WEPP Internet interfaces for forest erosion prediction. Journal of the American Water Resources Association 40(2), 299-309. doi:10.1111/J.1752-1688.2004.TB01030.X

Elliot WJ, Hall DE, Robichaud PR (2010) Forest Service peak flow calculator - estimated peak flow using curve number technology for burned areas (Version 2010.10.28). US Department of Agriculture, Forest Service, Rocky Mountain Research Station, Moscow, ID. Available at http://forest.moscowfsl.wsu.edu/fswepp/ermit/peakflow [Verified 14 April 2012]

Flanagan DC, Livingston SJ (Eds) (1995) WEPP user summary. US Department of Agriculture, Agricultural Research Service, National Soil Erosion Research Laboratory, NSERL Report No.11. (West Lafayette, IN).

Flannigan MD, Stocks BJ, Wotton BM (2000) Climate change and forest fires. The Science of the Total Environment 262(3), 221-229. doi:10.1016/S0048-9697(00)00524-6

Foltz RB, Robichaud PR, Rhee H (2009) A synthesis of postfire road treatments for BAER teams: methods, treatment effectiveness, and decision making tools for rehabilitation. US Department of Agriculture, Forest Service, Rocky Mountain Research Station. General Technical Report RMRS-GTR-228 (Fort Collins, CO). Summary available at
http://forest.moscowfsl.wsu.edu/BAERTOOLS/ROADTRT/ [Verified 14 April 2012]

Hawkins RH, Greenberg RJ (1990) WILDCAT4 Flow Model. University of Arizona, School of Renewable Natural Resources, Tucson, AZ.

Hudak AT, Morgan P, Bobbit MJ, Smith AMS, Lewis SA, Lentile LB, Robichaud PR, Clark JT, McKinley RA (2007) The relationship of multispectral satellite imagery to immediate fire effects. Fire Ecology 3(1), 64-90. doi:10.4996/FIREECOLOGY.0301064

Jain TB, Pilliod DS, Graham RT (2004) Tongue-tied. Wildfire (JulyAugust), 22-26.

Jordan P, Turner K, Nicol D, Boyer D (2006) Developing a risk analysis procedure for post-wildfire mass movement and flooding in British Columbia. In 'First specialty conference on disaster mitigation, 23-26 May 2006, Calgary, Alberta, Canada'. Canadian Society of Civil Engineers Publ. DM-013. (Montreal, QC) pp. 1-10.

Keeley JE (2009) Fire intensity, fire severity, and burn severity: a brief review and suggested usage. International Journal of Wildland Fire 18, 116-126. doi:10.1071/WF07049

Kokaly RF, Rockwell BW, Haire SL, King TVV (2007) Characterization of post-fire surface cover, soils, and burn severity at the Cerro Grande Fire, New Mexico, using hyperspectral and multispectral remote sensing. Remote Sensing of Environment 106, 305-325. doi:10.1016/J.RSE. 2006.08.006

Lentile LB, Holden ZA, Smith AMS, Falkowski MJ, Hudak AT, Morgan P, Lewis SA, Gessler PE, Benson NC (2006) Remote sensing techniques to assess active fire characteristics and post-fire effects. International Journal of Wildland Fire 15, 319-345. doi:10.1071/WF05097

Lewis SA, Lentile LB, Hudak AT, Robichaud PR, Morgan P, Bobbitt MJ (2007) Mapping ground cover using hyperspectral remote sensing after the 2003 Simi and Old wildfires in southern California. Fire Ecology 3(1), 109-128. doi:10.4996/FIREECOLOGY.0301109

Margaris NS, Koutsidou E, Giourga F (1996) Changes in traditional Mediterranean land-use systems. In 'Mediterranean desertification and land-use'. (Eds CJ Brandt J Thornes) pp. 29-42. (Wiley: Chichester, UK)

Miller JD, Safford HD, Crimmins M, Thode AE (2009) Quantitative evidence for increasing forest fire severity in the Sierra Nevada and southern Cascade Mountains, California and Nevada, USA. Ecosystems 12, 16-32. doi:10.1007/S10021-008-9201-9

Moody JA, Martin DA (2009a) Synthesis of sediment yields after wildland fire in different rainfall regimes in the western United States. International Journal of Wildland Fire 18, 96-115. doi:10.1071/WF07162

Moody JA, Martin DA (2009b) Forest fire effects on geomorphic processes. In 'Fire effects on soils and restoration strategies'. (Eds A Cerdà, PR Robichaud) pp. 41-79. (Science Publishers: Enfield, NH)

Morgan P, Hardy CC, Swetnam T, Rollins MG, Long LG (2001) Mapping fire regimes across time and space: understanding coarse and fine-scale fire patterns. International Journal of Wildland Fire 10, 329-342. doi:10.1071/WF01032

Myronidis D, Arabatzis G (2009) Evaluation of Greek post-fire erosion mitigation policy through spatial analysis. Polish Journal of Environmental Studies 18(5), 865-872.

Napper C (2006) Burned area emergency response treatments catalog. USDA Forest Service, National Technology and Development Program, Watershed, Soil, Air Management 0625 1801-STTDC. (San Dimas, CA)

Natural Resources Conservation Service (2005) 'WinTR-55 model.' USDA, Natural Resource Conservation Service, West National Technology Support Center. (Portland, OR). Available at http://www.nrcs. usda.gov/wps/portal/nrcs/detail/national/ndcsmc/?cid=stelprdb1042198 [Verified 14 April 2012]

Neary DG, Ryan KC, DeBano LF, Landsberg JD, Brown JK (2005a) Introduction. In 'Wildland fire in ecosystems: effects of fire on soil and water'. (Eds DG Neary, KC Ryan, LF DeBano) US Department of Agriculture, Forest Service, Rocky Mountain Research Station, General Technical Report RMRS-GTR-42-vol. 4. pp. 1-17. (Ogden, UT) 
Neary DG, Ryan KC, DeBano LF (Eds) (2005b) Wildland fire in ecosystems: effects of fire on soil and water. US Department of Agriculture, Forest Service, Rocky Mountain Research Station, General Technical Report RMRS-GTR-42-vol. 4. (Ogden, UT)

Orlemann A, Saurer M, Parsons A, Jarvis B (Eds) (2002) Rapid delivery of satellite imagery for burned area emergency response (BAER). In 'Proceedings of the ninth Forest Service remote sensing applications conference', 8-12 April 2002, San Diego, CA. [CD-ROM] (American Society for Photogrammetry and Remote Sensing: Bethesda, MD)

Parsons A, Robichaud PR, Lewis SA, Napper C, Clark J, Jain T (2010) Field guide for mapping post-fire soil burn severity. US Department of Agriculture, Forest Service, Rocky Mountain Research Station, General Technical Report RMRS-GTR-243. (Fort Collins, CO)

Peppin D, Fule PZ, Sieg CH, Beyers JL, Hunter ME (2010) Post-wildfire seeding in forests of the western United States: An evidence-based review. Forest Ecology and Management 260, 573-586. doi:10.1016/ J.FORECO.2010.06.004

Pierson FB, Robichaud PR, Spaeth KE (2001) Spatial and temporal effects of wildfire on the hydrology of a steep rangeland watershed. Hydrological Processes 15, 2905-2916. doi:10.1002/HYP.381

Ponce VM, Hawkins RH (1996) Runoff curve number: Has it reached maturity? Journal of Hydrologic Engineering 1(1), 11-19. doi:10.1061/ (ASCE)1084-0699(1996)1:1(11)

Renschler CS (2008) GeoWEPP: the geo-spatial interface for the Water Erosion Prediction Project homepage. Available at http://lesami.geog. buffalo.edu/projects/active/geowepp/ [Verified 14 April 2012]

Robichaud PR (2000) Fire effects on infiltration rates after prescribed fire in northern Rocky Mountain forests, USA. Journal of Hydrology 231-232, 220-229. doi:10.1016/S0022-1694(00)00196-7

Robichaud PR (2005) Measurement of post-fire hillslope erosion to evaluate and model rehabilitation treatment effectiveness and recovery. International Journal of Wildland Fire 14, 475-485. doi:10.1071/WF05031

Robichaud PR, Elliot WJ, Pierson FB, Hall DE, Moffet CA (2006) Erosion risk management tool (ERMiT) (Version 2006.01.18). US Department of Agriculture, Forest Service, Rocky Mountain Research Station (Moscow, ID) Available at http://forest.moscowfsl.wsu.edu/fswepp/ [Verified 14 April 2012]

Robichaud PR, Lewis SA, Laes DYM, Hudak AT, Kokaly RF, Zamudio JA (2007a) Postfire soil burn severity mapping with hyperspectral image unmixing. Remote Sensing of Environment 108, 467-480. doi:10.1016/ J.RSE.2006.11.027

Robichaud PR, Elliot WJ, Pierson FB, Hall DE, Moffet CA, Ashmun LE (2007b) Erosion risk management tool (ERMiT) user manual, version 2006.01.18. US Department of Agriculture, Forest Service, Rocky Mountain Research Station, General Technical Report RMRS-GTR188. (Fort Collins, CO)

Robichaud PR, Lewis SA, Ashmun LE (2008) New procedure for sampling infiltration to assess post-fire soil water repellency. US Department of Agriculture, Forest Service, Rocky Mountain Research Station, Research Note RMRS-RN-33. (Fort Collins, CO). Available at http:// forest.moscowfsl.wsu.edu/BAERTOOLS/MDI/ [Verified 14 April 2012]

Robichaud PR, Ashmun LE, Sims B (2010) Post-fire treatment effectiveness for hillslope stabilization. US Department of Agriculture, Forest Service, Rocky Mountain Research Station, General Technical Report RMRSGTR-240. (Fort Collins, CO). Available at http://forest.moscowfsl.wsu. edu/BAERTOOLS/HillslopeTrt/ [Verified 14 April 2012]

Spigel KM, Robichaud PR (2007) First-year post-fire erosion rates in the Bitterroot National Forest, Montana. Hydrological Processes 21 , 998-1005. doi:10.1002/HYP.6295

Thomas BE, Hjalmarson HW, Waltemeyer SD (1997) Methods for estimating magnitude and frequency of floods in the southwestern United States. US Department of the Interior, Geological Survey, Water-Supply Paper 2433. (Denver, CO)

USDA Forest Service (2004) Forest Service Manual 2520, Amendment No. 2500-2004-1. US Department of Agriculture, Forest Service (Washington, DC). Available at http://www.fs.fed.us/im/directives/ fsm/2500/2520.doc [Verified 14 April 2012]

van Wagtendonk JW, Root RR, Key CH (2004) Comparison of AVIRIS and Landsat ETM+ detection capabilities for burn severity. Remote Sensing of Environment 92, 397-408. doi:10.1016/J.RSE.2003.12.015

Westerling AL, Hidalgo HG, Cayan DR, Swetnam TW (2006) Warming and earlier spring increase western U.S. forest wildfire activity. Science 313(5789), 940-943. doi:10.1126/SCIENCE.1128834

Williams AAJ, Karoly DJ, Tapper NJ (2001) The sensitivity of Australian fire danger to climate change. Climatic Change 49, 171-191. doi:10.1023/A:1010706116176 